\title{
THE LEGAL STUDIES OF TRUCKING AND WAREHOUSING IN SUPPORTING THE SMOOTHNESS OF OUTFLOW AND INCOMING GOODS AT THE PORT
}

\author{
Sulistiowati $^{* *}$ dan Saida Rusdiana ${ }^{* * *}$ \\ Business Law Department and Civil Law Department \\ Faculty of law Universitas Gadjah Mada, Yogyakarta \\ Jalan Sosio Yustisia No.1, Bulaksumur, Sleman, D.I. Yogyakarta, 55281
}

\begin{abstract}
This legal study discusses the provision of trucking and warehousing of goods services and services at the port. This study is intended to address issues related research problems and directions arrangements in the provision of trucking and warehousing of goods services and services at the port. This study uses the empirical juridical approach of practices in the truck transportation of goods and warehousing services in the port, while the results of the study are presented in the form of descriptive analysis. The study results concluded that it is necessary for institutional capacity of port authorities as the organizer of the cultivated commercially port to perform the function of government in the harbour. Port Authority sets the capacity of the service, organizing auctions and provision of related services to cooperate with trucking and warehousing services provider in the harbour.
\end{abstract}

Keywords: port, trucking, warehousing, port authority.

\section{Intisari}

Kajian hukum ini membahas mengenai penyediaan jasa truk angkutan barang dan jasa pergudangan di pelabuhan. Kajian ini dimaksudkan untuk menjawab permasalahan penelitian terkait permasalahan dan arah pengaturan dalam penyediaan jasa truk angkutan barang dan jasa pergudangan di pelabuhan. Kajian ini menggunakan pendekatan yuridis empirik dari praktek penyediaan jasa truk angkutan barang dan jasa pergudangan di pelabuhan, sedangkan hasil penelitian disajikan dalam bentuk deskriptif analitis. Hasil kajian diperoleh kesimpulan bahwa diperlukan peningkatan kapasitas kelembagaan otoritas pelabuhan sebagai penyelenggara pelabuhan yang diusahakan secara komersial sehingga mampu menjalankan fungsi pemerintahan di pelabuhan. Otoritas Pelabuhan menetapkan kapasitas layanan, menyelenggarakan lelang penyediaan jasa terkait dan melakukan kerjasama penyedia jasa trucking dan warehousing di pelabuhan.

Kata Kunci: pelabuhan, trucking, warehousing, otoritas pelabuhan.

\section{Pokok Muatan}

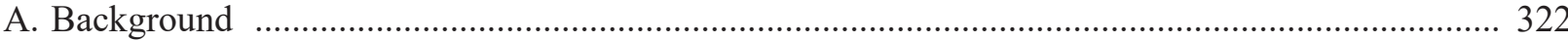

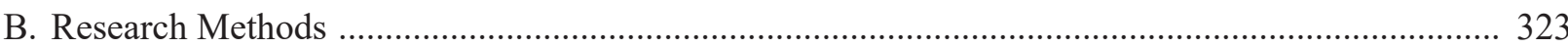

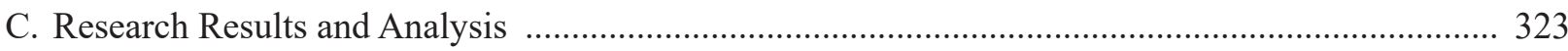

1. Trucking and Warehousing Problem Analysis ...................................................................... 323

2. The direction of the Operation and Regulation of Freight Services and Warehousing .............. 329

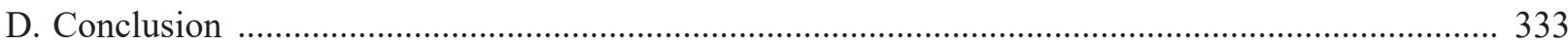

Research funded by PT Pelindo II Year 2014.

Correspondence Address: sulistyowati.fhugm@gmail.com.

*** Correspondence Address: saida_rusdiana@ugm.ac.id. 


\section{A. Background}

In a port management system, the port area can be divided into the area of land and water. ${ }^{1}$ Traditionally, land area is usually focused on the problem of accessing the waters. ${ }^{2}$ However nowadays, particularly in the context of logistics port, the land area plays an important role as a facility of intra and inter-modal transportation, loading and discharging place, warehousing, and distribution. ${ }^{3}$ Pursuant to laws and regulations in Indonesia, port commercial activity in a port that is managed commercially is administered by port authority. ${ }^{4}$ One of the main functions of the port authority is to regulate the use of the port's land and water area as well as to ensure the smoothness of goods flow in the port. ${ }^{5}$

In practice, this function is completed by the port authority by serving the service of warehousing, and managing truck flow from and to port. By achieving an efficient warehousing system in the port, its throughput will increase as well. By providing storage facility through a warehouse, the port authority can provide other kinds of services, such as cargo consolidation and containers distribution. ${ }^{6}$ The service of warehousing as container distribution and cargo consolidation has an increasingly important role along with the trend of freight containerization and the increase of goods traffic volume at ports in Indonesia. ${ }^{7}$ The warehouse area as the container distribution is utilized for loading and discharging containers. Further, such cargos are carried by truck heading to the final point. Meanwhile, the warehouse for cargo consolidation is used for organizing and loading goods to the containers that will be transported by the vessel through the port terminal. From the flow mentioned above, it is clear that the warehousing system shall be supported by other facilities such as a temporary stacking yard and facility for loading and unloading.

However, in reality, the performance of some port related services does not fully support the smoothness of goods distribution. There are still complaints regarding the performance of warehousing and trucking service. "For example, some ports in Indonesia exceed their yard occupancy ratio ("YoR"). This situation worsens traffic condition, and in turn negatively affects goods distribution. Goods transportation service from and to the port also has a strategic role in supporting smooth outflow and incoming goods. However, until today, most of the main ports in Indonesia has not been connected through the railways. ${ }^{9}$

This condition encourages the domination of trucking transportation over other modes of transportation in serving the outflows/incoming goods in port. This domination of freight truck in serving the outflows/incoming goods in port can create a bottleneck situation if it is not properly managed. This is readily apparent from bad traffic condition in the port area due to the imbalance between the capacity of the road network and the movement of the freight trucks. Besides that, the high movement from the freight trucks also potentially causes damage to the road network.

The elaboration mentioned above shows that

\footnotetext{
See, for example Article 1 of Law No. 17 of 2008 on Shipping (hereinafter "Shipping Law") (State Gazette 64/2008, Supplement of State Gazette 4849) (defines port as a place that consists of the land and waters).

Khalid Bichou, 2005, Maritime Security: Framework, Methods, and Applications. Report to UNCTAD, United Nations Conference on Trade and Development, Geneva, p. 15 Procedure of the Harbour Master Office and Port Authority.

Titik Purwinarti, "Prosedur Pengurusan Dokumen Barang Masuk Gudang Ekspor, Prosedur Pengangkutan Barang Ekspor Dan Prosedur Penanganan Dokumen Impor”, Jurnal Ekonomi dan Bisnis, Vol. 11, No. 1, June 2011, pp. 01-08. Ibid.

Sudibyo M. Wiradji, "Warehousing Business Grows But Delivery Problems Linger”, The Jakarta Post, 2 March 2015. Editor Beritasatu, "Urgensi Akses KA Pelabuhan", http://www.beritasatu.com/blog/tajuk/4322-urgensi-akses-ka-pelabuhan.html, accessed on 3 July 2017
} 
until today there are still problems in providing service related to the warehousing or goods transportation by truck. The focus of this legal study is an effort to create a conducive business climate affected by the availability of the laws and regulations that are in favour of freight trucking services becomes a compulsory requirement for strengthening the quality of freight services in port.

Further, to create an effective warehousing service, the alignment of various loading and unloading activities is needed. With inequality from one of the activities will be implicated to the inefficiency and in the long run will hindrance the smoothness of goods distribution in port. In consideration of such matter, this writing discusses the problems in creating an effective goods transport services and warehousing in supporting the smoothness of goods distribution in the port.

This legal study on the provision of port's trucking and warehousing services is discussing the problems as follows: First, what are the problems of the provision of freight trucking and warehousing in supporting the smoothness of goods flow in the port? Second, what is the direction of the operation and regulation of freight truck and warehousing services in supporting the smoothness of goods flow in the port?

\section{B. Research Methods}

This legal study employs juridical empiric approach from the practice of the procurement of goods transport services and warehousing in the port. The character of this study is descriptive analytics to elaborate the problems and discrepancy in creating goods transport and warehousing services in supporting the smoothness of traffic at the port.

The conceptual framework of the study is constructed with an objective from the operation of ports in Indonesia and an effort in creating the competitiveness of ports from various best practices of logistics port operations. The juridical empiric approach is performed by analysing the problems and discrepancy between the regulation and practice of the provision of goods transport and warehousing services in Indonesia.

\section{Research Results and Analysis \\ 1. Trucking and Warehousing Problem Analysis \\ Problem analysis in developing logistics ports} among others are as follows: (a) Fragmentation of Logistics Activities in Water and Land Area of the Port; (b) Separation of the Authority and Hinterland of the Port; (c) The Focus of the Improvement of Port's Performance is Only on the Side of Port's Waters; (d) Has Not Been Directed as Logistics Port; (e) The utilization of dry-port has not yet been optimal: Indonesia has five dry-ports, namely Container Terminal (Terminal Peti Kemas - TPK) Tebing Tinggi in South Sumatra, TPK Gedebage in West Java, TPK Solo Jebres in Central Java, and TPK Rambipuji in East Java. One of the reasons why dry-ports are not utilized optimally is because the inability of train to compete with the mode of road transport. ${ }^{10}$ For comparison of the total cost of transporting containers from Gedebage dry-port to Tanjung Priok Port utilizing road transport mode and train, it results that the total cost of transporting containers sized 20 feet utilizing road transport mode is more expensive $\mathrm{Rp} 550.000,00$ than utilizing train. Whereas for containers sized 40 feet, transporting them using road transport is cheaper Rp 400.000,00 than train; ${ }^{11}$ (f) Port Authority's capacity for planning and coordinating stakeholders at the port. The analysis of the problems is provided using the fish bone diagram in Chart 1 .

\footnotetext{
10 Biro Komunikasi dan Informasi Publik, "Dry Ports Potential di Indonesia belum dikembangkan secara optimal", http://www.dephub.go.id/ berita/baca/potensi-dry-port-di-indonesia-belum-dikembangkan-secara-optimal-2275/?cat=QmVyaXRhfHNlY3Rpb24tNjU=, accessed on 3 July 2017.

11 Ibid.
} 


\section{Chart 1.}

Problem Analysis of Trucking Service in Port

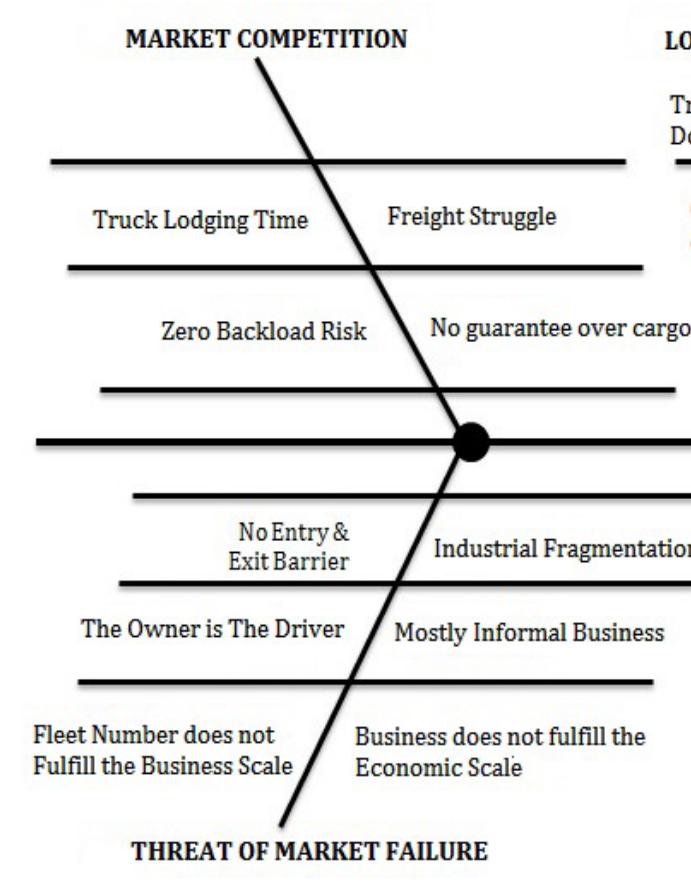

Source: Processed by the Author, 2016.

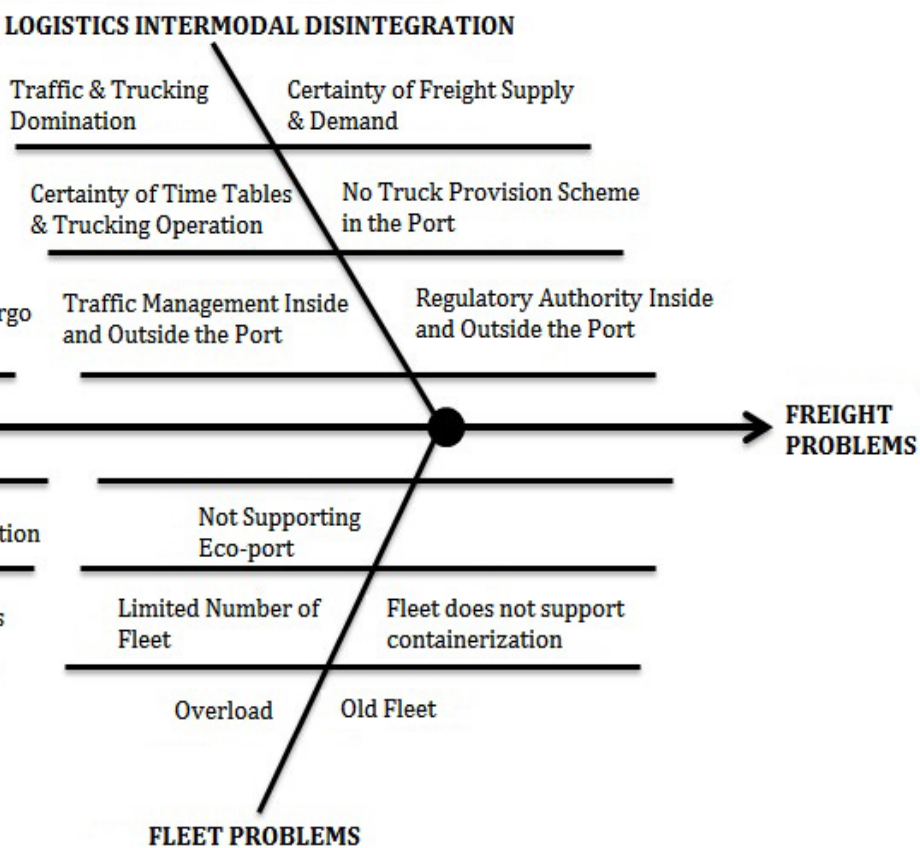

a. Operational Problems of Trucking Service

\section{1) Cargo Overload}

Problems related to overload is caused by incompatibility between road category and truck's load. Problems can be seen, among other things, when a road passed by the truck to go to the location of the goods' owner or factory is not compatible with the cargo transported. Besides that, overloading also influenced by the uncertainty of the truck's load and the inefficiency of the business operation that encourages the businessmen to load excess cargos. This excess is expected to be able to cover operational cost. However, this overload resulted in road damage.

In fact, the government has made regulations that oblige every driver or freight company to follow the provisions of the loading procedure, conveyance, vehicle dimensions and road category (Article 168 paragraph (1) Law No. 22 of 2009). Furthermore, a supervision towards the freight transport has also been enacted utilizing weighing equipment (Article 169 paragraph (1) and (2) Law No. 22 of 2009). The awareness from the stakeholders particularly the truck driver to obey the applicable regulations as well as the lack of legal enforcement of overload violations.

\section{2) Old Fleet}

Many trucks are not road worthy according to their period of use, so it is necessary to rejuvenate of the fleet. The rejuvenation of truck fleet is also still a serious problem since the 
operation of the freight truck does not fulfil economic business scale.

\section{3) Fleet Has Not Supported Containerization}

There is a trend to manage the port to cargo containerization. However, the operators face limited funding to change the fleets as per cargo containerization needs.

\section{4) Has Not Supported Eco-port}

The operators' ignorance to rejuvenate fleets makes most of the fleets operated are old. These old fleets are certainly not eco-friendly.

b. Problems Analysis of the Provision of Warehousing Service are as follows:

1) Unsupportable Cargo Manifest Data to Be Accessed by Other Interested Institutions other than Customs and Not Maximal Use of Indonesia National Single Window "INSW")

Another hindrance faced is the problem in using the cargo manifest where it cannot be used simultaneously between the Customs and Quarantine Agency as the interested institutions. Cargo manifest is the list of trade goods that are transported by any mean of transport through the sea upon entering or leaving the Customs Area. During this time, when the cargos are entering the port, the cargo manifest is given to the Custom despite the fact that the Quarantine agency admits the difficulty in accessing it directly. Quarantine agency firstly has to ask permission to the Directorate General of Customs to access such document of cargo manifest. ${ }^{12}$

So far, according to the regulations of Minister of Finance, indeed it is not explained directly that the cargo manifest can be given to any party other than Customs. ${ }^{13}$ Based on the applicable regulations, cargo manifest is a direct responsibility of the carrier to the Customs Office where its use is restricted so that the access to the document is limited for Customs only. However, Customs is not the only party that has the interest to use the data on such cargo manifest document. Quarantine, as the institution that has supervisory function towards the safety of the goods that are entering the territory of Indonesia also has the same interest to be able to access the information early regarding the goods transported to Indonesia that become the subject of its supervisory duty. Such document of cargo manifest is needed by the Quarantine in performing such function.

To give access to Quarantine to cargo manifest, Minister of Agriculture issued Decision No. 02/Kpts/ OT.140/1/2007 On Document and Animal Quarantine Certificate so that the shipping agent can give the cargo

\footnotetext{
Interview with Dr. Arifin Tasrif, Head of Quarantine Complience Center, Ministry of Agriculture, on 25 October 2014.

Regulations related to the submission of cargo manifest (inward manifest and outward manifest) to the Customs are: Minister of Finance Regulation No. 39/PMK.04/2006 on the Submission Procedure of the Mode of Transport's Notice of Arrival, Arrival Manifest of the Mode of Transport and Departure Manifest of the Mode of Transport; Directorate General of Customs Regulation No. P-10/BC/2006 on the Submission and Administration Procedure of the Mode of Transport's Notice of Arrival, Arrival Manifest of the Mode of Transport and Departure Manifest of the Mode of Transport as has been lastly amended through Directorate General of Customs Regulation No. P-19/BC/2006; Directorate General of Customs Regulation No. Per-5/BC/2011 on the Notice Procedure of Mode of Transport's Arrival and Departure Manifest In Transporting Import and Export Goods to and From the Customs Area in Integrated Custom Service Area;
} 
manifest to the Quarantine Agency as a requirement for the issuance of Quarantine Certificate. Further, the Minister of Agriculture Regulation No. $\quad$ 18/Permentan/OT.140/3/2011 On Quarantine Document Service in the Electronic System of Indonesia National Single Window (INSW) also requires the presence of cargo manifest in the documents needed by the Quarantine Agency. However, in its practice, this access has not yet run. The Quarantine Agency admits that the implementation of INSW itself shall be accompanied with cooperation from all institutions. Cohesiveness and integration from all applicable regulations are needed to give the interested institutions access to the cargo manifest. It is needed particularly for increasing the effectivity of the port itself. ${ }^{14}$

2) The accumulation of goods that are not in place, Temporary Hoarding Place switches its function to be a warehouse in the Port

Temporary Hoarding Place (Tempat Penimbunan Sementara "TPS") in the Port functions as a consolidation place to accelerate the process of goods loading and unloading. Besides that, TPS also functions to the dwelling time of vessels so that the goods are not too long to be on the vessel thus the cost can be suppressed..$^{15}$ TPS is a building and/or a yard or other place similiar to it in Customs Area whose function is to hoard imported or exported goods while waiting for their unloading or loading. ${ }^{16}$

A problem arises when the importers leave their containers in TPS to cut costs burdened cheaper. Although there is a time limitation for them to take their cargos away, however, the average importers who do not have their own warehouse intentionally leave their containers in TPS since the rental cost that they have to burden is still cheaper than the cost they have to spend to rent a warehouse outside the Port. It shifts the function of TPS in the Port so it is no longer functions as a consolidation place but a long-term storage area. Because of such action from the importers, the available place in TPS is increasingly limited. Meanwhile, increasing the number of warehouse in the Port area is also not possible to be done since it is constrained by the land acquisition problems.

According to Minister of Finance Regulation No. 70/PMK.04/ 2007 on Customs Area and Temporary Hoarding Place that is later further regulated in Directorate General of Customs RegulationNo.P-20/BC/2007 on the Implementation Guidelines of Customs Area Establishment and Temporary Hoarding Place, hoarding cargos in TPS that is located in the Port area is assigned 30 days at the longest from the hoarding date. On the other hand, for cargos hoarding in TPS that is located outside the Port, it obtains a

Interview with Dr. Arifin Tasrif, Head of Quarantine Complience Center, Ministry of Agriculture, on 25 October 2014.

Interview with Pelindo II, on 25 October 2014.

Article 1 paragraph 7 Minister of Finance Regulation No. 70/PMK.04/2007 on Customs Area and Temporary Hoarding Place. 
longer period, 60 days at the longest from the hoarding date. Cargos hoarded in TPS which have not been taken out during such period will be declared as Goods that Are Declared Unowned and shall be moved to the Custom Hoarding Place (Tempat Penimbunan Pabean). ${ }^{17}$ Although there is a time limit on the duration of the goods to be hoarded, such regulations have not stipulated consequences for the importers who intentionally leave their cargos in TPS.

Regarding such matter, the Port Authority also criticizes the same thing. ${ }^{18}$ According to Article 83 paragraph 1 (h) of the Law No. 17 of 2008 on Shipping, it becomes one of the duties of the Port Authority to ensure the smoothness of the goods flow in the Port. However, the Port Authority contends that it has lacks legal basis to move the containers that are intentionally left in TPS by the importers to minimalize their cost. Besides, the regulation regarding TPS is under the regulatory authority of the Minister of Finance, and its utilization is primarily for custom interest. It does not give much room for other ministries that also have interests in TPS.

\section{3) The Potential Risk of Pest and Infection From The Commodity Goods That Are Caused Among Others by: \\ a) Inexistence of On Board Quarantine Inspection}

System in accordance with INSW

According to the Law No. 16 of 1992 on Animal, Fish and Vegetation Quarantine, a quarantine inspection which is done towards a goods carrier can be done on board of a vessel or after the cargos are unloaded. Such law and the Government Regulation No. 82 of 2000 on Animal Quarantine do not give any further information regarding quarantine inspection that can be performed on board of a vessel or inspection after the goods are unloaded. However, what differentiates both of them is the action that is done to the goods if after the inspection it is infected with pests or infection that is prohibited to be brought in. If the goods that have been inspected on board later known have been infected by a pest that is prohibited, thus such goods will be rejected and denied to enter the territory of Indonesia. If the goods have been unloaded and during the inspection, they are known have been infected by a pest that is prohibited, thus such goods will be destroyed. In Article 22 Government Regulation No. 14 of 2002 on Vegetation Quarantine, it is explained that if the goods carrier is originated

\footnotetext{
17 Article 14 Minister of Finance Regulation No. 70/PMK.04/2007 on Custom Area and Temporary Hoarding Place; Article 17 Directorate General of Custom Regulation No. P-20/BC/2007 on the Implementation Guidelines of Customs Area Establishment and Temporary Hoarding Place.

18 Interview with the Port Authority on 25 October 2014.
} 
from a country infected with an epidemic or having a high risk, an inspection towards such goods carrier is important to be performed on board of the conveyance.

Although it is not prohibited or obligated by the Laws, in its implementation, the Quarantine agency always performs the goods inspection when they have entered the place of entry or the port. The Quarantine agency admits that their role becomes more effective if they can perform an inspection on board of the vessel before the cargos are unloaded. ${ }^{19}$ Besides that, this matter will also decrease cargo hoarding in the port. Nonetheless, Quarantine agency admits that it has not obtained enough legal basis to accommodate this interest.

b) No Joint Inspection Between the Quarantine Agency and Custom

As a proof of the completion of customs' act, Customs issues the Approval Letter of Goods Release (Surat Persetujuan Pengeluaran Barang - "SPPB") which declares that the goods have been inspected and can be taken out of the Port. This issuance often becomes an issue since it does not require the Approval Certificate from the Quarantine Agency (KT9 and KH12). Often happens, the goods that have been taken out of the Port since they have completed all inspections under Custom and obtained SPPB, have to be brought back due to the unfinished business with the Quarantine Agency. During this time what becomes the issue is the vacuum of laws that regulate the integration of SPPB issued by Custom and KT9 and KH12 issued by Quarantine Agency.

c) The Absent of Service Standard of Loading and Unloading Because of the Difference of Standard Operating Procedure Applied in One Terminal to Another

Another obstacle that has to be faced in increasing the effectiveness of cargos loading and unloading in the Port is the difficulty to bring the cargos that have been unloaded from the conveyance to TPS or TPFT to be inspected. One of the reasons that cause this struggle is the terminal operators that have different standard of operations between one to another, so there are different bureaucracies to be taken to bring the cargos or containers to the hoarding or inspection place. ${ }^{20}$

According to Article

73 of Government Regulation No. 61 of 2009 on the Seaport,

Interview with Dr. Arifin Tasrif, Head of Quarantine Complience Center, Ministry of Agriculture, on 25 October 2014. 
in performing port business activities, Port Business Entity - Badan Usaha Pelabuhan shall provide a service to the port service users in accordance with the service standard set by the Government. In this regard, if there is a significant difference in the standard of operations among terminal operators that later hindrances the flow of goods loading or unloading, the government has the right to set the service standard for all operators.

4) The Requirement of Owner's Presence to Unpack Cargos

Article 5 from Directorate General of Customs Regulation No. P-07/BC/2007 on Physical Inspection of Imported Goods stipulated that the inspection towards imported goods can be started if; first, the importer or his proxy state that the imported goods are ready to be inspected; and second, the TPS Manager has prepared adequate human resources and the equipment of physical inspection related to the goods that will be inspected. The customs regulation does not stipulate a requirement for the goods' owner presence when unpacking the goods. However, the implementation of all this time is that unpacking goods shall only be done when the goods' owner has presented. ${ }^{21}$ Later, this becomes an obstacle to the port's effectivity.

5) 24/7 Port Service that Has Not

\section{Been Optimal}

Pursuant to Government Regulation No. 61 of 2009 on Seaport, it is stipulated that wherever possible, the port shall enhance its services to be able to serve 24 hours/day in line with the need for increasing the frequency of the vessel to load and unload goods. Nonetheless, in its implementation, the institutions involved in the Port have not been optimal yet in performing this regulation.

Referring to Article 9 of Government Regulation No. 82 of 2000 on Animal Quarantine, health inspection over the sanitation of goods' carrier is done physically and performed during the noon time except in certain circumstances according to the consideration of quarantine veterinarian it can be done during the night time. This regulation certainly obstructs the port operation that is expected to serve 24 hours/day. Besides that, although custom has issued a regulation that regulates 24 hours Custom service, in its implementation this service has not been maximized.

2. The direction of the Operation and Regulation of Freight Services and Warehousing
a. Direction of the Operation of Freight Services and Warehousing in Port
Table 1 below provides a discrepancy analysis between the factual issue and the expected condition.

Table 1.

Gap Analysis of Freight Services in Port

${ }^{21}$ Interview with Dr. Arifin Tasrif, Head of Quarantine Complience Center, Ministry of Agriculture, on 25 October 2014. 


\begin{tabular}{|c|c|c|c|}
\hline $\begin{array}{l}\text { STRATEGIC } \\
\text { ISSUES }\end{array}$ & $\begin{array}{c}\text { EXISTING } \\
\text { CONDITIONS }\end{array}$ & $\begin{array}{c}\text { EXPECTED } \\
\text { CONDITIONS }\end{array}$ & $\begin{array}{c}\text { DISCREPANCY } \\
\text { ANALYSIS }\end{array}$ \\
\hline \multirow[t]{2}{*}{$\begin{array}{l}\text { Integration of } \\
\text { Port Planning and } \\
\text { Hinterland }\end{array}$} & $\begin{array}{l}\text { - Separation between } \\
\text { logistic activities in } \\
\text { foreland, port, and } \\
\text { hinterland } \\
\text { - There has not been } \\
\text { collective effort from } \\
\text { relevant actors to make } \\
\text { mutual coordination }\end{array}$ & $\begin{array}{l}\text { - Integration of logistics } \\
\text { activities in foreland, } \\
\text { port, and hinterland in } \\
\text { supporting the efficiency } \\
\text { of logistics port }\end{array}$ & $\begin{array}{l}\text { - Integrating logistics } \\
\text { activities in Port's land } \\
\text { and water area } \\
\text { - Balancing the focus } \\
\text { on performance } \\
\text { improvement in the Port }\end{array}$ \\
\hline & $\begin{array}{l}\text { - } \text { Truck Domination in } \\
\text { Port } \\
\text { - Traffic in Port and its } \\
\text { Surrounding }\end{array}$ & $\begin{array}{l}\text { - Port Authority } \\
\text { guarantees smooth flow } \\
\text { of the port traffic } \\
\text { - Road Transport Mode } \\
\text { split and another mode }\end{array}$ & $\begin{array}{l}\text { - } \text { Certainty of Truck } \\
\text { Operational Hour in the } \\
\text { Port } \\
\text { - Integrated Traffic } \\
\text { Management } \\
\text { - } \text { Railway Access } \\
\text { Building to Port }\end{array}$ \\
\hline $\begin{array}{l}\text { Implementation } \\
\text { of competition } \\
\text { for the market } \\
\text { trucking in Port }\end{array}$ & $\begin{array}{l}\text { - There is competition } \\
\text { in the Market on going } \\
\text { (fight over passengers \& } \\
\text { lodging) } \\
\text { - Uncertainty of truck's } \\
\text { supply \& demand (zero } \\
\text { backload) } \\
\text { - There is no } \\
\text { implementation } \\
\text { regulation of BUP } \\
\text { Trucking }\end{array}$ & $\begin{array}{l}\text { - } \text { Certainty of demand \& } \\
\text { supply of truck service } \\
\text { - Only trucks that are } \\
\text { transporting that can be } \\
\text { in Port area }\end{array}$ & 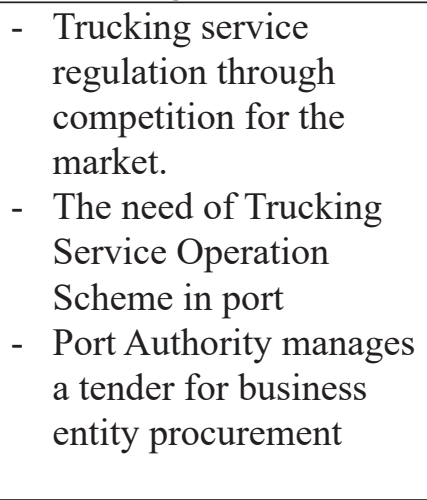 \\
\hline $\begin{array}{l}\text { Truck Operator's } \\
\text { Legal Entity } \\
\text { Status }\end{array}$ & $\begin{array}{l}\text { - Mostly informal } \\
\text { operator }\end{array}$ & $\begin{array}{l}\text { - Truck Operator's legal } \\
\text { entity status }\end{array}$ & $\begin{array}{l}\text { - } \text { Requirements of the } \\
\text { legal entity of operators } \\
\text { - Law No. } 17 \text { of } 2008 \\
\text { allows individual } \\
\text { business (in contrary } \\
\text { with the Law No. } 22 \text { of } \\
\text { 2009) }\end{array}$ \\
\hline $\begin{array}{l}\text { Market Failure } \\
\text { Threat }\end{array}$ & $\begin{array}{l}\text { - Industrial Fragmentation } \\
\text { - No entry \& exit barrier } \\
\text { to market } \\
\text { - } \text { The majority is informal } \\
\text { and individual operators } \\
\text { - } \text { The owner is the driver } \\
\text { - Number of fleet does } \\
\text { not reach the economic } \\
\text { scale } \\
\text { - Minimal number of fleet } \\
\text { rejuvenation } \\
\text { - Has not been } \\
\text { containerized }\end{array}$ & $\begin{array}{l}\text { - Operators consolidation } \\
\text { by forming legal entity } \\
\text { - Trucking industry that } \\
\text { is competitive and } \\
\text { sustainable }\end{array}$ & $\begin{array}{l}\text { - The government } \\
\text { facilitates operators } \\
\text { consolidation } \\
\text { - Market intervention to } \\
\text { support the competitive } \\
\text { industry }\end{array}$ \\
\hline
\end{tabular}




\begin{tabular}{|c|c|c|c|}
\hline $\begin{array}{l}\text { Distribution } \\
\text { Centre } \\
\text { Development }\end{array}$ & $\begin{array}{ll}\text { - } & \text { Limited role of } \\
\text { distribution centre } \\
\text { - } & \text { Logistics activities } \\
\text { fragmentation from } \\
\text { hinterland to port }\end{array}$ & 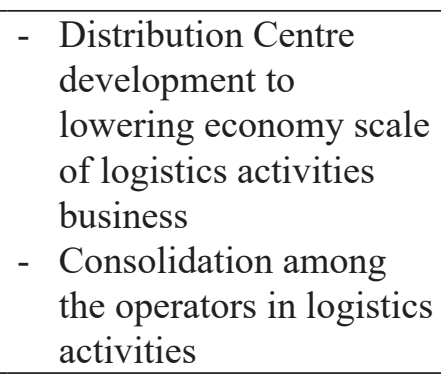 & $\begin{array}{l}\text { - RTRW support for } \\
\text { the development of } \\
\text { distribution centre } \\
\text { - Government facilitates } \\
\text { the consolidation among } \\
\text { the logistics operators. }\end{array}$ \\
\hline
\end{tabular}

Source: Processed by the Author, 2016.

Based on the discrepancy analysis mentioned above, the responsibility of the Port Authority to guarantee the smoothness of the traffic in the port is needed to be followed up by utilizing its authority to regulate the operation of trucking service in Port. Besides that, normatively, the legal framework regarding the role of the Port Authority and trucking services in Port that is commercially utilized is as follows:

1) Article 83 paragraph (1) letter $h$ Government Regulation No. 61 of 2009: "In order to carry out the regulatory and development function, controlling as well as the supervisory function of the Port's activities, the Port Authority has duties and responsibilities to ensure the smoothness of goods flow."22

2) Article 70 paragraph 1) letter 1 Government Regulation No. 61 of 2009: "Procurement and/or providing services related to the port which one of them is public transport to and from the port"; ${ }^{23}$ 3) Article 70 paragraph (2) Government Regulation No. 61 of 2009: "The activities above are performed by an individual(s) citizen of Indonesia and/or business entity." ${ }^{24}$ This stipulation of Article 70 paragraph (2) Government Regulation No. 61 of 2009 that allows an individual to provide public transport service in Port is in contrary to the Law No. 22 of 2009 (LLAJ) that obliges the operator of public transport (including freight transport) to be in the form of legal entity.

\section{b. The Regulation of Trucking Management in Port}

As a response to the matter mentioned above, the direction of the operation of truck services and goods transport in the Port is as follows:

1) Port Authority as the Operator of the Port governs:
a) Service Integration in Land and Water Area in supporting port's logistics activities;
b) Encouraging the Deve- lopment of Freight Trains;
c) The Needs of Supply and Demand of Truck Service in Port;
d) Minimum Service Stan-

22 Article 83 paragraph (1) letter h Government Regulation No. 61 of 2009 concerning Sea Port (State Gazette of the Republic of Indonesia Year 2009 Number 151, Supplement of State Gazette of the Republic of Indonesia Number 5070).

23 Article 70 paragraph (1) letter 1 Government Regulation No. 61 of 2009 concerning Sea Port (State Gazette of the Republic of Indonesia Year 2009 Number 151, Supplement of State Gazette of the Republic of Indonesia Number 5070).

24 Article 70 paragraph (2) letter 1 Government Regulation No. 61 of 2009 concerning Sea Port (State Gazette of the Republic of Indonesia Year 2009 Number 151, Supplement of State Gazette of the Republic of Indonesia Number 5070). 
2)

Competition for The Market of trucking service in Port. Port Authority manages a tender for business entities that provide trucking services in accordance with SPM;

3)

It is needed to have Implementation Regulation of Law No. 17 of 2008 related to the mechanism of procurement and/or services related to the port, particularly Public Transport from and to the Port. The mechanism suggested is the implementation of Quality Licensing (Tender) to choose the Legal Entities that provide freight transport service. For example: Demand for Freight Transport is 6 million TEUs/ year served by ten operators of Freight Transport.

4) The

Government facilitates the consolidation of small operators and individuals to form a new legal entity. As an incentive, the Government provides a fiscal incentive or credit facility for fleet rejuvenation.

\section{c. The Direction of the Regulation of Warehousing Management in the Port}

Suggestions to handle port warehousing services to overcome various problems mentioned above are as follows:

1) Strengthening the Capacity of Port Authority Institution as the operator of the port that is commercially utilized and performing the role as the representative of the Government in Port. Related to the warehousing service, the role of the Port Authority among others are as follows: a) The Port
Authority as the operator of the Port that is utilized commercially set an operational standard and port service procedure and warehouse service standard in Port; b) The provision scheme is a cooperation between the Port Authority (Port operator) with an operator. The Port Authority cooperates with the individual(s), citizen(s) of Indonesia and/or legal entity. The cooperation can be made in the form of: (1) land leasing; (2) warehouse leasing; and/ or (3) stacking leasing; c) Port Authority performs supervision and evaluation related to the fulfilment of the minimum service standard of the port warehousing service.

2) Refinement of Warehousing Service in Port: a) Integration of port services to become logistics port, among other by optimizing the role of dry port so that not all clearance process is performed in the port; b) Optimization the Function of Integrated Physical Inspection Site (Tempat Pemeriksaan Fisik Terpadu - “TPFT"), so that all process related to physical inspection of goods is performed in one place and one chain of process; c) Port Procedure Simplification by performing Joint Inspection for all related activities (Customs and Quarantine); d) Rationalization of Container Stay Tariff to YOR; e) Optimization of INSW as an information portal for all port's activities.

3) Suggestion on the Regulation of Container Stay Time Limit, related to: a) Container Stay Tariff; b) Hoarding Time Limit; c) The penalty for the violation of hoarding time limit; d) Longstay Container Displacement; and e) Acquisition Mechanism of the long-stay container so that containers hoarded in the 
warehouse or the temporary hoarding place until a certain period can be recognized as the State Property.

4) The consistency of Law Enforcement over the Violation of Long-stay Container.

\section{Conclusion}

The result of the legal study on the operation of trucking and warehousing service in the port produces conclusion as follows: First, the problems with the provision of truck service, freight transport and warehousing in the port in supporting the smoothness of goods' flow in the port are among others: a) Ongoing competition in the market; b) Market failure threat towards the provision of trucking service in the Port; c) Problems related to the absence of integration between the service in land water area of the port; d) Problems related to the operationalization of trucking service; e) Cargo manifest data that is not easy to be accessed by other related institutions other than the Custom and the utilization of INSW that is not maximum; f) Goods hoarding that is happening not in its place, namely the Temporary Hoarding Place switches its function to be a warehouse in the Port; g) The potential risks of commodity pest infections; h) Requirement of the owner's presence to unpack the cargos; i) 24/7 Port Service that has not been maximum.
Second, the direction of the operation and regulation of the port's freight truck service and warehousing in supporting the smoothness of goods flow in port, among others: a) to answer the current problems as well as anticipate the increase in the flow of goods loading and unloading in the Port, the operation of ports in Indonesia which are utilized commercially is important to develop service integration in waters or land area; b) political will from the government, stakeholders, and all relevant parties in Port is needed. It is hard to create efficiency if there is no awareness and mutual will to implement the regulations that have been made; c) internal regulation regarding the outflows of freight truck in the Port to smoothen the goods traffic, decrease the logistics cost, and overcome the problem of dwelling time in the Port is also necessary to be made; d) strict law enforcement shall be implemented optimally if there is a need to create an effective performance of goods transport service and commodity movement in the Port; e) duties, authorities, and role of the government particularly the Port Authority in performing its function as the conductor in Port shall be done optimally, furthermore the capacity of the institution is also needed to be strengthened so that the problems and obstacles that arise in the current provision of goods transport services and commodity movement can be resolved.

\section{REFERENCES}

\section{A. Books}

Bichou, Khalid, 2005, Maritime security: framework, methods, and applications. Report to UNCTAD, United Nations Conference on Trade and Development, Geneva.

\section{B. Journal Article}

Purwinarti, Titik, "Prosedur Pengurusan Dokumen Barang Masuk Gudang Ekspor, Prosedur Pengangkutan Barang Ekspor Dan Prosedur Penanganan Dokumen Impor", Jurnal
Ekonomi dan Bisnis, Vol. 11, No. 1, June 2011.

\section{Newspaper}

Sudibyo M. Wiradji, "Warehousing business grows but delivery problems linger", The Jakarta Post, 2 March 2015.

\section{Internet}

Biro Komunikasi dan Informasi Publik, "Dry Ports Potential in Indonesia Had Not Been 
Optimally Benefited", http://www.dephub. go.id/berita/baca/potensi-dry-port-diindonesia-belum-dikembangkan-secaraoptimal-2275/?cat=QmVyaXRhfHNlY3Rpb2 $4 t \mathrm{Nj} U=$, Last access on 3 July 2017.

Editor Beritasatu, "Urgensi Akses KA Pelabuhan", http://www.beritasatu.com/blog/tajuk/4322urgensi-akses-ka-pelabuhan.html, Last access on 3 July 2017.

\section{E. Regulations}

Law No. 16 of 1992 on Animal, Fish and Vegetation Quarantine (Republic Indonesia State Gazette of 1992 No 56, Supplement of the Republic Indonesia State Gazette No. 3482).

Law No. 17 of 2008 on Shipping (Republic Indonesia State Gazette of 2008 No. 64, Supplement of the Republic Indonesia State Gazette No. 4849).

Law No. 22 of 2009 on Road Traffic and Transport (Republic Indonesia State Gazette of 2009 No. 96, Supplement of the Republic Indonesia State Gazette No. 5025).

Government Regulation No. 82 of 2000 on Animal Quarantine (Republic Indonesia State Gazette of 2000 No. 161, Supplement of the Republic Indonesia State Gazette No. 4002).

Government Regulation No. 14 of 2002 on Vegetation Quarantine (Republic Indonesia State Gazette of 2002 No. 35, Supplement of the Republic Indonesia State Gazette No. 4196).
Government Regulation No. 61 of 2009 concerning Sea Port (State Gazette of the Republic of Indonesia Year 2009 Number 151, Supplement of State Gazette of the Republic of Indonesia Number 5070)

.Minister of Finance Regulation No. 70/ PMK.04/2007 on Customs Area and Temporary Hoarding Place.

Minister of Agriculture Regulation No. 18/ Permentan/OT.140/3/2011 on Quarantine Document Service in the Electronic System of Indonesia National Single Window (INSW).

Directorate General of Custom Regulation No. $\mathrm{P}-07 / \mathrm{BC} / 2007$ on Physical Inspection of Imported Goods.

\section{F. Others}

Interview with Dr. Arifin Tasrif, Head of Quarantine Complience Center, Ministry of Agriculture, on 25 October 2014.

Interview with Pelindo II, on 25 October 2014.

Interview with the Port Authority on 25 October 2014 